\title{
Bowling Alleys and Playhouses in London, 1560-90
}

\begin{abstract}
Recreational and domestic alleys provide a useful paradigm for understanding the construction of commercial stages in the 1560s and 1570s, and they provide essential and overlooked contexts that situate playhouses within the wider leisure ecology of Elizabethan London. Bowling alleys' construction, reception, and activity present striking similarities with multipurpose theatre buildings, and they lay down models not only for those managing recreational space but also for those in opposition to it. They help supply the vocabulary of recreational enterprise later attached to theatrical playing spaces and lay foundations — in all senses - for the development of London's theatre industry itself.
\end{abstract}

Bowling alleys might not seem an obvious parallel to the Elizabethan spaces that staged the plays of Robert Greene, Thomas Kyd, John Lyly, Christopher Marlowe, George Peele, William Shakespeare, and Robert Wilson, but they are closely tied up with the playhouse industry of mid-to-late sixteenth-century London. Among chief concerns for builders of playhouses in this period are issues of city regulation and opposition from local residents; choosing open or closed, indoor or outdoor venues; and finding skilled constructors to build or adapt acquired space to the desired ends. Each of these issues is equally pertinent to bowling alleys, whose proprietors were navigating such paths long before purpose-built structures for commercial drama were widely established in the city. Bowling alleys therefore provide a useful paradigm for understanding the construction of long-standing commercial stages in the 1560s and 1570s, and they provide essential and overlooked contexts that situate playhouses within the wider leisure ecology of Elizabethan London. Scholars have posited various models of influence for playhouse construction, particularly classical amphitheatres and contemporary animal baiting arenas, none of which has proved to be entirely persuasive; ${ }^{1}$ by contrast, theatre historians have not before considered bowling alleys to be a major influence

Callan Davies (C.J.Davies@kent.ac.uk) is a research associate at the University of Kent. 
on playhouse development, but their construction, reception, and activity present striking similarities with multipurpose theatre buildings. Bowling alleys, moreover, lay down models not only for those setting up and managing recreational space but also for those in opposition to it. They help supply the vocabulary of recreational enterprise later attached to theatrical playing spaces and lay foundations - in all senses - for the development of London's theatre industry itself.

In this article, I briefly explore the history of bowling and its sixteenth-century developments, before focusing on how bowling alleys can help historians better understand the boom in playhouse building in and around London in the 1560s and 1570s and beyond. I explore the significance of alley spaces in the Elizabethan capital - a contentious topic for lawmakers, builders, and particularly poor tenants suffering from an exploitative rental market. Recreational development of such spaces cannot be entirely separated from their domestic uses, and the proliferation of bowling alleys should be understood alongside the housing crises and related building restrictions of these years. Playhouse builders, in turn, followed examples set down by alley development, and both the Curtain (ca 1577) and the First Blackfriars Playhouse (1576) sat similarly within existing space in alley-like set-ups. Bowling alley construction, moreover, has a long history that informs stage construction - as the limited evidence surrounding John Brayne's Red Lion playhouse (1567) illustrates, along with wider building regulations across the Elizabethan city. Finally, I focus on two examples of bowling alleys in the 1570 s and 1580s - the case of James Croft's servant and Henry Naylor's ex-ecclesiastical alleys in the Blackfriars - to show how bowling alleys can offer models for better understanding developments in and reactions to the playing industry.

\section{Bowling and Playing}

Bowling had long been a popular pastime in London by the mid-sixteenth century. As early as the fifteenth century, the state was issuing proclamations condemning bowling on Sundays (along with other long-standing pastimes such as bull-baiting). ${ }^{2}$ Bowling was a popular and accessible form of recreation that encompassed a host of different forms of 'bowling' activity; for instance, 'nine holes', variations on types of different bowls, and sometimes the throwing of coits (as described in more detail below). It included different throwing objects, and Gervase Markham explains that the skill of the game lies in 'choosing out ... ground; and prenetrating the winding, hanging, and many turning aduantages of the same; whether it bee in open wide places or in close allies'; for Markham, 'your flat bowles' are 'best for allies, your round byazed bowles for open 
grounds'. ${ }^{3}$ Across the course of the sixteenth century, alleys for bowling grew in size and frequency, and John Stow identifies the sport's popularity as a negative encroachment upon formerly significant space. Writing of the area north of Moorgate (the route that leads in the period in which Stow is writing towards the Shoreditch playhouses), Stow observes that the area is 'of late years inhabited (for the most part) by Bowyers, Fletchers, Bow-string makers and such like, now little occupied; Archery giving place to a number of bowling Allies, and Dicing houses, which in all places are increased, and too much frequented'. ${ }^{4}$ For Stow, bowling represents the decline of legitimate pastimes such as archery and its replacement with illegitimate and potentially damaging or corrupt pursuits.

Gambling itself is a part of bowling alley activity. ${ }^{5}$ John Earle's character book Microcosmographie (1628) sketches a rare picture of the goings on within such alleys and paints a vibrant picture of one of early modern London's most popular recreational offerings; alleys are places where 'there are three things thrown away besides Bowls, to wit, time, money and curses. ${ }^{6}$ Earle explains that the sport engenders extreme quarrels over trivial matters (bowling is the 'Schoole of wrangling') and beyond the players themselves bowling is popular with spectators: 'The best Sport in it is the Gamesters, and he enioyes it that lookes on and bets not'. ${ }^{7}$ Earle's description — in a short but vivid characterization of the space offers glimpses of the capaciousness of a 'Bowle Alley', in which being a 'Gamester' - by which he seemingly means those playing for money, but which can also simply indicate a participant in the sport ${ }^{8}$ — is but one possibility on offer; his description suggests not only that multiple versions of the game exist but also that such alleys provided a range of different forms of participation 'besides bowls', in Earle's words, from spectatorship, to carding and gambling, to other forms of betting on the sport itself.

Reaction to existing alleys corroborates Earle's account. William More, landlord of much of the Blackfriars liberty in London, wrote a series of draft petitions in the 1570s against three bowling alleys set up by Henry Naylor (the fencer who trained Richard Tarlton, the famous comic clown of Elizabethan England) in the cloisters of the former friary. He noted that they combined bowling with a 'Dising howse' (which he describes as one of the three 'Alleys' itself) and drew people in 'gret nomber aswell prentices and seruauntes as others beinge for the most parte verye poore men, who there spende and consvme their tyme \& uerye moche moneye to their undoyinge useinge there also detestable swerynge Noyse and Cryinge to the great offence $\&$ annoyaunce $\&$ disturbance of all the Neighboures'. 9 These alleys were multipurpose hubs that drew people to them for a host of different recreational activities. 
In their versatility, they are strikingly similar to playhouses, for which the capacious term 'play' is of chief importance. Indeed, in the same way a 'play' is the subject of a playhouse, so too are 'plays' the activity contemporaries describe taking place in bowling alleys. More's petitions refer to 'a plaie Comonlye called nyne holes \& a place as yt ys reported provided for a game called black and white or ells for a Disinge howse, To which plaies' great numbers resort, and More refers to these various 'plays' collectively under the umbrella term of 'comon bowlinge Alleys. ${ }^{10}$ These petitions indicate that the institution of the bowling alley is host to a range of 'games' as well as to a range of different forms of engagement, from gambling to bowling to spectating. In this capaciousness, bowling alleys have close parallels with the developing commercial theatre industry, which is similarly invested in the capaciousness of 'play'. Glynne Wickham has shown, for instance, how the flexibility of the term in this period insists on relationships between, rather than separations of, different forms of recreation: "The two words "recreation" and "pastyme" supply the key to the ambiguity transferred into English from ludus and extending outwards into both "play" and "game". ${ }^{11}$ Lawrence Clopper has also shown how the flexible term 'play' encompassed a range of activities from the medieval period onwards. ${ }^{12}$ Playing companies used spaces such as the Curtain, Theatre, Bull, Bell, and Bel Savage not only for performances of drama, but for a range of differing performance activities, as Richard Tarlton's extemporizing feats evince, along with the frequent fencing prizes played at these venues and recorded in the Masters of Defence book. ${ }^{13}$

The multifaceted nature of both playhouses and bowling alleys accords with Erika Lin's recognition that commercial theatre 'was fully imbricated in the representationally porous and generically hybrid forms of entertainment that characterized seasonal events' - those such as May games, morris dances, and Robin Hood plays. ${ }^{14}$ By tying the experience of playgoing to a 'vast network of historically specific, habitual modes of thinking and feeling', Lin situates the creation of the category of 'theatre' as a 'negotiation' with other forms of entertainment, including a game culture that, as this article suggests, extends to bowling. ${ }^{15}$ Tom Bishop has similarly sought to restore the semantic significance of 'play' and 'player' to our understanding of Elizabethan drama in detecting a slow shift from 'player' to 'actor' that has eclipsed how, historically, the theatre was 'a form of play or an event which include[d] various kinds of games or play-routines. ${ }^{16}$ These discursive contexts reinforce how bowling alleys and their 'plays' occupied a significant role in Lin's 'network' of thought and feeling, a network that houses multiple forms of play within a defined physical space. Unlike many other forms of 'game', such as May games or dicing and gambling — which do not necessarily 
require a fixed physical space or identifiable 'institution' or enterprise — bowling is widely situated in commercial alleys in the sixteenth century in the years surrounding the growth of 'houses' for commercial theatrical performance.

Accordingly, plenty of contemporary evidence exists of playhouse visitors using such spaces in similar ways to the varied engagement of bowling alley punters: some enjoy parts of the play, some enjoy the social space, some enjoy the food, and some the dancing. In 1612, the Middlesex General Sessions of the Peace issued an order 'for Suppressing of Jigges at the ende of the Playes', in which they claim that 'diverse cutpurses and other lewd and ill-disposed persons in great multitudes do resort thither [to playhouses] at the end of every play'. ${ }^{17}$ Edward Gayton, moreover, reflecting on playhouse-going practices of the early seventeenth century, observed that spectators came 'not to study at a Play-house, but love such expressions and passages, which with ease insinuate themselves into their capacities. ${ }^{18}$ He goes on to paint a picture in which certain scenes or set-pieces might be desired without care to the coherency of a whole play.

On top of the scrappiness of play performances, playhouses supplied audiences with food and drink in similar ways to neighbouring institutions — including, as I explore in detail below, 'alley' structures that provided 'in-house' goods. Paul Hentzner, on his travels to England in the 1590s, observes of bear-baiting arenas and more broadly of the city's playhouses: 'In these theatres, fruits, such as apples pears and nuts, according to the season, are carried about to be sold, as well as ale and wine'19 — an observation that archaeological digs over the past forty years have confirmed with regard to playhouses. ${ }^{20}$ Many of the playhouses of this period also doubled as victualling institutions: the Theatre was adjoined by a former brewhouse of uncertain use (currently under archaeological investigation), Henslowe's Rose was related to his erstwhile partner John Cholmeley's drinking establishment, and inn playing spaces were connected by their very nature to the food and drink industry. The number of other spaces and playhouses that incorporated such victualling establishments or had connections with nearby businesses remains as yet unclear. Given the breadth of activity on offer, the bustle of playhouse-goers making their way merrily in and out of the auditorium space, presumably indulging in other aspects of the playhouse entertainment culture besides the drama on stage at a given moment, is perhaps hardly surprising (see, for instance, Richard Madox leaving in distaste at the 'matter' of 'scurvy play' set out by a 'virgin, which there proved a freemartin without voice' in 1582). ${ }^{21}$ Henry Chettle goes so far in 1593 to suggest that 'While Plays are used, half the day is by most youths that have liberty spent upon them, or at least the greatest company drawn to the places where they frequent'. ${ }^{22}$ This knotty and syntactically odd 
passage suggests that whether or not they observed the play performance itself, London's younger demographic hung around playhouses and spent their 'liberty' within (or surrounding) them. Like the bowling alleys with their array of options (to be a gamester in an alley, or to observe the gamester, or simply to play), playhouses provided punters with a variety of ways to engage with their manifold recreational offerings. They align themselves with bowling alleys as one of early modern London's entertainment hubs. In light of this alignment, the affinities between the 'game' space and the playhouse indicated here provide further evidence to support Gina Bloom's claim that the 'gaming culture of early modern London eased the transition to a commercial theater':23 indeed, as I demonstrate further on, the playing industry was subject to the adapted strategies and vocabulary used to regulate and respond to other types of 'play'.

'Play', then, is a crossover term that links the 'house' and the 'alley' as sites of multipurpose entertainment - not least in that both entertainment spaces use 'play' to describe their activities. Perhaps unsurprisingly, then, official documentation and social commentary of the period closely link playhouses and bowling alleys. When More was writing his complaint about Naylor's alley in the Blackfriars, he spoke of 'a plaie Comonlye called nyne holes', and great numbers of London's apprentices and servants resorted to these 'plaies'. ${ }^{24}$ Complaints from the City of London Corporation, moreover, regularly listed playing alongside a whole variety of disreputable recreation, thereby aligning it with the sort of undesirable and newly-overbearing activity Stow identified north of Moorgate. ${ }^{25}$ In popular print, antitheatrical tracts such as T.F.'s Newes from the North (1579) drew upon similar associations: 'I call to witness the Theaters, Courtaines, Heaving houses, Kissing booths, Bowling alleys, and such places where the time is so shamefully misspent. ${ }^{26}$ All individuals opening and constructing playhouses in the 1570 s would have therefore seen playing overlapping (and competing) with other recreational pursuits often subject to the same pressures, particularly bear-baiting, dicing and carding, fencing, dancing, and of course bowling. They would have been aware of the affinities that any playing space would share with the houses designed for such recreational activities, and perhaps were inspired, motivated, or influenced by them - directly or indirectly. Not only were playhouses 'built right next to gaming establishments', as Bloom explains, ${ }^{27}$ but they were conceptual neighbours in all areas, from private petitions and civic documentation to the print market. Above and beyond many other forms of game, bowling offers a particularly strong parallel with playing because it draws together connotations of the term 'play' to link the physical spaces of the 'house' and the 'alley' that accommodated such forms of recreation. 


\section{Alley Life and Conversion}

The word 'house' as it features in 'playhouse' had a more capacious definition than 'a freestanding structure'; Andy Kesson explains that "Then and now, "house" could refer to a space, indoor or outdoor, and not simply an individual building. ${ }^{28}$ Its flexibility opens it up to related building terminology in early modern London, in particular the 'alley'. Alleys were, broadly speaking, narrow lanes or passages enclosed by surrounding tenements and buildings (or other forms of cultivated or closed space). In line with current definitions in the $O E D$, the early modern use of the term included anything from walkways to places to play sport in - practical terminology that delimits the sporting use of an 'alley' for bowling, ${ }^{29}$ where the first dictionary example tellingly includes the synonym 'house' (from 1542). The parallel with 'house' reappears throughout the century, and in 1573 a reissued proclamation against unlawful games aligns the 'comen house alley or place of bowling coyting cloyse coyles half bowle tennys Disinge table or cardinge'. ${ }^{30}$ The term is fluid when it comes to construction in early modern London, however, and the word 'alley' encompasses not only sporting venues but sites adapted for residential use. The early modern alley was therefore a contentious space that lay at the centre of a range of building practices and commercial land use in the sixteenth century, from recreation to slum ownership.

Indeed, alleys were at the centre of wider concerns about building in London during these busy years of expansion, overcrowding, and migration. Those seeking to build alleys or build within alleys were following a trend of capitalizing upon the built-up areas around tenements. Such practices concerned the city from at least the 1560s and 1570s, during which it sought to control the 'pestered houses enormyties in auncient allies \& diuerse other thinges therein conteyned', including a similar order to carpenters not to 'conuert or alter any auncient messuage or tenement into allies or suche like'. ${ }^{31}$ In part, such alleys proved attractive options to any owner or lessee looking to expand or develop property in the wake of further regulations that prohibited what Court of Common Council documents term 'new building. The queen introduced London-specific new building regulations in a proclamation on 7 July 1580 that restricted the increase of any new buildings with fresh foundations. This proclamation was followed with an order from the city to 'enquyre ... of all offenses againste the sayd proclaymatyon in places pretended exempte and within three myles compasse wythout the walles of the sayd cytye. ${ }^{32}$ Yet the attractiveness of alley construction had been apparent much earlier, and by the 1580 s it was simply bolstered by an opportunity to 
circumvent these new proscriptions against fresh foundations by capitalizing on existing space.

Alleys represent for the London Corporation one example of 'close' or intimate space that harboured crowds and as such required regulation. Accordingly, they frequently appear in the records of the aldermen and the Court of Common Council alongside playing spaces, inns, and 'houses' of play. An act of Common Council issued in 1579 included, in its appendix, a series of regulations that set a precedent for the London authorities' attempt to suppress playing entirely. 33 Within the act's set of orders, however, the authorities give significant attention to the policing of alleys:

Where many landlordes \& fermers of alleys or of greate houses conuerte into small habitacions do kepe uitailing houses shoppes or cellers for utteringe of drinke uitaille ... to thinhabitantes of thos alleys or small habitacions: all suche shalbe utterlye disallowed forbydden to be used. ${ }^{34}$

Contemporaries identified alley space - and not just explicitly recreational space - as a potentially exploitative commercial opportunity for landlords who could monopolize the food and drink market of local residents. Henry Chettle provides further colour to this practice in his sketch of alley life in Kind-Hart's Dream (1590), ventriloquizing the ghost of Richard Tarlton. He describes residents labouring for their accommodation in alleys' tippling houses and through other services, and being manipulated into spiralling debt to their landlords or landladies: 'Some Landlords having turned an old Brew-house, Bake-house, or Dye-house into an Alley of tenements, will either themselves, or some at their appointment, keep tippling in the fore-house (as they call it) and their poor tenants must be enjoined to fetch bread, drink, wood, coal, and such other necessaries, in no other place'. ${ }^{35}$ Alleys therefore represented micro-markets that served food and drink to their tenants (in domestic use) or their punters (in recreational use). While we are aware of pricing structures that determined entry to playhouse auditoriums (or more precisely their wider complexes), I have found no surviving evidence of what it might cost to enter a bowling alley; given the enclosed nature and multiple offerings of the space, proprietors quite possibly charged for entry into the complex (though, of course, we cannot assume this practice), in the manner loosely assumed for playhouses, to secure punters' spending on on-site amenities and activities. The descriptions of alley landlords' nefarious enterprises align them with the victualling supplies of early modern playing spaces as described 
above, and they suggest that alleys provide a blueprint for a commercial playing ecology that brings together food, drink, and entertainment.

\section{Building and Conversion}

Given the anxiety about 'new building' in local and national regulation, constructors looked to various building practices to complete new projects, in particular 'conversion' - a term used in official documentation of this activity. Catherine Richardson and Tara Hamling's study of the early modern house emphasizes the ongoing repurposing and development that occur to any one early modern building during its lifetime - and especially during the so-called era of 'Great Rebuilding' in the two hundred years that followed fifteenth century. ${ }^{36}$ William C. Baer, who examines the nature of the house-building industry in the mid-sixteenth century and its considerable expansion in the suburbs, has also explored the processes involved in constructing such buildings. He explains that limited data exists for those who built and sold property, yet given the regulatory environment and the overcrowding of urban space, it took 'especially determined persons to build houses speculatively and get them sold or leased'. ${ }^{37}$ He also notes that for many builders, construction was not their main profession; rather, they had other trades that sometimes fell within the building trade and so allowed them to capitalize on their own skills. While Baer's studies focus on those building accommodation, these same factors apply to those constructing recreational spaces, including bowling alleys and playhouses. Almost all of those involved in construction and conversion of such spaces utilized their particular expertise and hired accordingly (including master builders for practical coordination of the site), acting as managers of a construction project. Baer's description of a builder fits perfectly with all of the known proprietors of 1560 s-80s play spaces - Richard Farrant, James Burbage and John Brayne, Philip Henslowe, Henry Naylor, and others discussed below: 'They were the projectors, promoters and leaders who conceived and initiated the project, lined up land and financing and oversaw it to completion. Builders could hire the variety of special trade or craft functions and professional skills that they could not perform themselves'. ${ }^{38}$

Such special functions would include the likes of the Carpenters' Company, whose skills were central to the burgeoning construction industry. Carpenters in this period would have been deeply familiar with both 'new building' (on fresh foundations) and conversion; when first caught in the act of dismantling the Theatre in 1599, the Burbages' chief carpenter, Peter Streete, told Henry Johnson 'that they tooke yt downe but to sett yt upp in uppon the premisses in an other forme. ${ }^{39}$ 
This building practice is typical for Elizabethans, and indeed Peter Streete was in legal trouble previously, in a Star Chamber case from 1590, for aggressively (that is to say, with bills, swords, daggers, pistols, and a crew of confederates) chasing further work in a case in which he was to 'have the Tymber and Leade of your sayde Subiectes ould house' and to 'pull Downe the sayde ould Tenement and in the place and Roome thereof to erect and sett upp and perfectly to fynishe one other newe Tenement. ${ }^{40}$ Nine years later, Streete found himself in a very similar altercation over the Theatre. Streete's involvement points to his ongoing expertise in this typical practice of Elizabethan construction, and the repurposing of both materials and land indicates a tightly regulated building environment in which carpentry conversion was crucial and habitual.

The Red Lion playhouse, built in 1567, provides stronger connections between the Carpenters' Company and the nascent playhouse industry, and gestures to the simultaneous facility carpenters had with both playing spaces and bowling alleys. Little is known about the Red Lion playhouse beyond two legal quibbles between its apparent proprietor John Brayne, grocer, and two individuals from the Society of Carpenters in $1567 .{ }^{41}$ Some six or so years after receiving his freedom from the Grocers (at the rough age of twenty-six), ${ }^{42}$ Brayne sought to erect 'one Skaffolde or stage for enterludes or playes. ${ }^{43}$ Perhaps lacking the experience or skill to construct such a project, following the model of a 'builder' set out above, Brayne hired a number of contractors to build his stage. The only reason the Red Lion project is known to posterity is thanks to two quarrels resulting from Brayne's arrangement with William Sylvester and John Reynolds. We cannot know how much more work was done in addition to what is laid down in the performance bond for the stage construction (Reynolds) and the quarrel in the Carpenters' Court Books (Sylvester), though we might guess that either by Brayne himself or another contractor performed further work. We do not know how long or for how many performances the stage was in use or Brayne designed it for, though we know that at the time of the quarrel Brayne was gearing up to a performance of the 'storye of Sampson'. ${ }^{4}$

Members of the Carpenters' Company involved in constructing the stage were well acquainted with building to theatrical specifications. The company was frequently contracted to build various pieces for pageantry and accessions, and the court books show that, like other livery companies, it had its own leisure spaces to maintain; in 1573, the company paid 12 pence for mending the bowling alley and again that year paid out for a broom for the alley. ${ }^{45}$ The precise nature of the quarrel about the playhouse - beyond what we can glean from the trial at King's Bench, in which Reynolds complains that Brayne 'impeded, disturbed, 
and prohibited' his work ${ }^{46}$ — remains ultimately a mystery. Yet the carpenters involved clearly had their own relationship to maintaining recreational space in the 1560s and 1570s. Their own bowling alley, listed for repair here in 1573, provides an in-house example of the form of labour carpenters would have been contracted to do not only on the pageant work that frequently appears in these books but also in their capacity as individual tradespeople who would work on spaces such as the Red Lion or on bowling alleys across London. Their own company experience suggests that they had the skills necessary to do what is here the very basic work of repair of the space, but their ownership and maintenance of a bowling alley also exemplify the way in which bowling alleys can influence or bleed into other forms of recreational construction - especially given that in prime years of theatrical development in the late 1560s and early 1570s, bowling alleys were far more widespread and familiar spaces than playhouses. ${ }^{47}$

Alley spaces thereby provide a blueprint for constructing entertainment institutions across the city and suburbs, particularly thanks to their adaptability. The experience of carpenters such as Streete and others, who frequently work on 'converting' buildings and spaces, underscores how conversion is equivalent to 'building' in Elizabethan London, especially in an environment that frequently reused and recycled costly materials and spaces. Alleys provide the perfect example of how the building industry habitually approached existing spaces and adapted them to various useful ends, domestic and commercial.

Two early playing spaces represent precisely such a trend for conversion and adaptation that follows this building model, and these spaces testify to and expand S.P. Cerasano's characterization of 'the transitory playhouse' - an inherently impermanent architectural space. ${ }^{48}$ Residents and tenants repeatedly identified the First Blackfriars Playhouse as converted space within existing 'houses', thereby fitting the model the Common Council articulated of seeking to 'conuert or alter any auncient messuage or tenement into allies or suche like' (where 'suche like' can encompass 'playhouses', given the association of the word 'alley' with 'house' in recreational discourse of the period). ${ }^{49}$ Richard Farrant was the builder of the First Blackfriars Playhouse when, managing boy singers and players, he was deputy to the master of the Chapel Royal (William Hunnis) and master of the Choristers of St George's Chapel, Windsor Castle. His activity in the area is traceable through preserved paperwork kept by the owner of much of the postdissolution Blackfriars from 1559 onwards, William More.

The surviving documentation includes not only a lease but a letter to More in which Farrant explains that he intended to 'pull downe one perticion and so make of one too rooms one'.50 In his various disparaging comments about Farrant's 
tenure in these rooms or 'house', More later bemoans its conversion into playing space through the building work done on the property: 'Farrant pretended unto me to use the house only for the teaching of the Children of the Chapel, but made it a continual house for plays, to the offense of the precinct, and pulled down partitions to make that place apt for that purpose. ${ }^{51}$ Like the Common Council, More seeks (retrospectively) to police the conversion of existing space into alleys or 'houses' for recreational use, precisely what Farrant intended to and successfully did do. Tellingly, More's response to this playhouse follows closely his earlier objections to Naylor's bowling alleys in the vicinity, a subject I return to in detail below. In both cases, the conversion of space into commercial recreational enterprises provides the grounds for objections, and Naylor's activity produced an earlier converted 'alley' that matches Farrant's subsequent converted 'house', two sites of play only metres apart from each other in distance and within a similar frame of time.

The Curtain playhouse, too, bears remarkable similarities with alley space that suggest we should see it as partly related to the recreational alley developments of mid-to-late Elizabethan London. Theatre historians often see the Curtain as a new-built structure, however much it has been subject to negative assumptions about its status, usefulness, and quality. In part, the illustrations of two possible playing spaces in Shoreditch in the View of the Cittye of London from the North towards the Sowth (ca 1598) — one to the west and one to the east, both with flags $^{52}$ — suggest large upright buildings, yet both are flanked and even adjoined by neighbouring structures. Recent archaeological innovations reveal the Curtain not only to be rectangular (perhaps confusing further its identification on the View of the Cittye), but to be constructed in an area flanked by surrounding buildings and behind an existing tenement that fronts onto Curtain Road. Its set-up in this regard makes it a close parallel to alley developments that build up in existing narrow lanes, passages, or enclosed areas. By 1607, moreover, contemporaries identify the Curtain by reference to alley space, echoing the language of tenement conversion in the 1570s: Richard West describes how

The garden alleyes paled on either side;

Ift be too narrow, walking there you slide,

Into a house among a bawdy crew,

Of damned whores; I theres your whole delight. ${ }^{53}$

Even though West describes them as garden alleys, he does not characterize the houses adjoining this area of Shoreditch as expansive fields; rather, the houses speak to archaeological evidence that the playhouse made use of surrounding 
properties and was situated within existing structures in much the same way as the city's bowling alleys (and of course other non-recreational structures). Tellingly, perhaps, the closest surviving analogue space to the Curtain playhouse, based on archaeological findings, is the Corral de Comedias in Almagro. ${ }^{54}$ The Curtain's surprisingly close similarity with this later Spanish theatre space demands a re-evaluation of assumptions about the 'stand-alone' nature of English amphitheatres (a feature that David Amelang's recent comparative study uses to frame English playhouses as distinctly different from their Iberian counterparts). Rather, evidence suggests a powerful similarity with Spanish corrales, which 'were spaces left in between buildings that were later recycled for theatrical use.'.5 Such a definition would serve the recreational uses of London's alleys, and the Curtain, equally well.

These two brief examples indicate how alleys pave the way for conversion (rather than straightforwardly 'new built' properties) to be a central paradigm for playhouse building in Elizabethan London. An emphasis on the ostensibly 'archetypal' playhouse - typically that of the Theatre and its successor the Globe, has obscured the centrality of conversion in theatre history. Scholars frame both these spaces as innovative design landmarks that literally and metaphorically stand alone. Indeed, Gabriel Egan emphasizes the relative impossibility of pinning influences on the Theatre's appearance. ${ }^{56}$ While the Theatre's 'circularity' is certainly idiosyncratic, such emphasis on its uniqueness risks eliding the relationship of bowling alley development to playing spaces in the years surrounding its construction. When we view playhouses in context with one another, conversion or adaptation (a term that covers spaces such as inns used fluidly as playing venues) are by far the most common modes of construction: the Bel Savage, Cross Keys, Bull, and Bell (and early Boar's Head) were all inn adaptations; St Paul's, Blackfriars, and Curtain were all conversions or sorts that used or adapted existing spaces in and between buildings; Newington Butts was seemingly a conversion of existing tenement structures. ${ }^{57}$

Only the Theatre in the 1570s was, by all intents and purposes, a new-built structure; yet even that building sat alongside an existing decayed barn, later converted into a number of tenements. ${ }^{58}$ When the Theatre was first built, the barn remained in disrepair and was made structurally a part of the playhouse. Deponent Richard Hudsons explains that the 'barne was very ruynous and decayed soe as then the same was fayne to be shored vpp vnto the Playhouse Called the Theater, ${ }^{59}$ an observation other deponents seconded. As ongoing archaeological work is continuing to reveal, moreover, the playhouse was in some way attached to a former medieval brewhouse on its north side, a structure that was in turn 
itself adapted to the use or needs of the playhouse and its entrances, exits, and external areas. ${ }^{60}$ On the evidence of those who went to see it, the Theatre could well have had the look of a semi-conversion or alley-like space, similar to the Curtain. While clearly an architectural idiosyncrasy, its relationship to existing structures is not as clean-cut as an initial scan of the evidence might suggest. In the period up to 1599 , further complications exist: while the Rose (1587) and the Swan (1594) were new buildings (the former 'converted' from its previous form in an expansion of 1592), the Boar's Head (1598) was a clear conversion of the former inn, for which dimensions of the conversion survive. While the Globe (1599) was a new structure, it borrows its timber from the disassembled Theatre and its erection could be described in early modern terminology as a 'conversion', with the court cases surrounding the Theatre's disassembly using the term 'convert' to mean repurposing the materials out of which the Theatre was made. ${ }^{61}$ Conversion and adaptation are building methods that draw on alley construction for various commercial ends. Recreational discourse frames the alley and the house as close relatives and associates both with 'play'; rather than characterizing the playhouse as a unique and freestanding development, we must see it in light of the adaptation of alleys for both domestic and entertainment uses. Alleys supply a model not only of repurposing existing space but of commercial leisure ecology, as multipurpose spaces that cater to visitors through victualling, entertainment, and adaptation.

\section{Going to a Play}

Bowling alleys serve not only as examples of practical construction that help map how playhouses developed throughout the sixteenth century; they also provided the vocabulary with which both proprietors and opponents responded to playhouses. Recent work has emphasized how existing gaming cultures inform the reception of newly-developing commercial theatre in the mid-to-late sixteenth century, in particular Bloom's observations about antitheatrical discourse and Lin's connections between festive culture and theatricality. The discursive shifts these studies identify are directly tied to the framing and reception of the commercial playing industry, and Joachim Frenk observes that the 'pro- and antitheatrical debates of the time were similar to the general debates about which games should be lawful and which should not' 62 — including proclamations dating back to Henry VIII's reign and earlier activities, including bowling, as noted above. Clopper brings the longer history of this antitheatrical discourse to light in his work on medieval responses to playing and gaming and its direct lines into 
sixteenth-century discourse, where antitheatrical responses derive not from aversion to performed theatre but 'in opposing ... the games of the world' — notably, summer games and 'unhonest' ludes. 63

Bowling forms part of this longer history of 'unhonest' games and is part of this wider context for antitheatrical strategies, though bowling alleys' immediate connections with the boom in playhouse building in the 1560s and 1570s require more detailed examination. While part of a longer inheritance of antitheatrical discourse, bowling alleys also offer a useful synchronic parallel with the theatre industry as a whole - its relationship with regulation and local opposition as well as the development of longer-term business models that aimed to cultivate multiple indoor and outdoor spaces for playing across London and its suburbs: a practice seemingly limited only to bowling alleys and playhouses.

This final section therefore offers two case studies that build upon the recognized affinities between antitheatricalism and games and play: a servant of James Croft, who sought to build an additional alley to his existing space in 1580, and Henry Naylor, the converter of the Blackfriars cloisters into three bowling alleys. Both of these examples suggest that the bowling industry foreshadows later developments in and responses to theatrical entrepreneurship. Studies of antitheatrical discourse have recognized parallels between gaming and theatre; these case studies go further in revealing how bowling can situate the potential rhetorical posturing of antitheatricalism - a 'literary genre requiring only the adoption of a morally earnest persona by the writer ${ }^{264}$ — in concrete, urban examples. In so doing, they demonstrate how bowling alleys and playhouses were materially, politically, and culturally connected for individual Londoners beyond the performative rebukes of print, pulpit, and proclamation.

\section{Croft's Servant}

In September 1580, James Croft wrote to the then mayor Nicholas Woodrofe to ask permission for Croft's servant to finish building a bowling alley, which he had already begun. Croft describes it as a 'close Alye for the recreation of honest Citisens to bowle in fowle wether', and Croft goes on to point out that the unnamed servant has a licence and is very well-behaved. ${ }^{65}$ Woodrofe responded to Croft somewhat boldly that the would-be bowling-alley-builder already owned an outdoor alley, one the mayor described as 'one great Allye', and 'now is making the second a close Allye'. Furthermore, the mayor observed that 'Ther is adioyning unto it, and ther wold be thre Allyes', suggesting that if built the alley would contribute a third such space 'within half an acre of grounde' — possibly all three 
bowling alleys or possibly including an alley of residential or other commercial use, along lines discussed above. ${ }^{66}$ The exchange paints a striking picture of the proposed location (not mentioned with any geographical specificity), in which potentially three or more (depending on interpretation of the wording) alleys cluster within striking distance of each other, at least two offering bowling as recreation. The proposal and the environmental contexts that inform Woodrofe's stay of building give some credence to John Stow's anxiety that such spaces are 'increased, and too much frequented'. ${ }^{67}$ Indeed, the mayor proceeded to launch into a familiar condemnation of the pastime, dismissing its honest intents by claiming that it attracts not only so-called good citizens but 'all sortes indifferently euen the worse and meanest'. He also reiterated wider Common Council concerns that bowling alleys offer other various pursuits, including 'dicing, carding and table play' and the strong potential for 'great assemblie of persones dangerous for infection, quarrels, and other disorders'. ${ }^{68}$

On the one hand, Woodrofe's actions demonstrate the city's attempt to police the numbers of constructed bowling alleys - a regulatory endeavour that London authorities also oversaw with regard to taverns ${ }^{69}$ - thereby foreshadowing attempts to control playhouse numbers later in the 1590 s and 1600 s. $^{70}$ Yet we can glean from these letters further commercial strategies regarding the bowling industry that surround the distinction between 'open' and 'close' space. Croft's servant already ran one 'great Allye' and sought to build a 'close Allye' to supplement it. The term 'close' is a contentious one for London authorities, and while flexible, it seems to indicate, across Corporation material, spaces that are private or suspect, away from open visibility, that offer room for secret meetings or matches, and that restrict open air and air flow: while perhaps not strictly 'indoor', they are covered or intimate structures, closely bunched, or related to, in the phrasing of one letter, 'the inconvenience ... of nere byldinges. ${ }^{71}$ Close space was subject to suspicion from authorities throughout the period, with especial regard for recreational gatherings, for which the Council explicitly distinguished between closed and open spaces as evident from their repeated distinctions between 'close Allyes or open' for bowling: ${ }^{72}$ the difference suggests a structural and potentially a social difference between the two.

'Close' alleys likely denominate covered or indoor spaces, given that the same terminology was also applied to playing spaces much more easily understood to be 'indoor'. A plague precept from the late 1560 s prohibited, for instance, 'assembles of great numbers of multitudes of people vnto diuerse and seuerall ... Innes and places of this Cittie and the liberties \& suburbes of the same to here and see certayne Stage playes enterludes and other disguisanges ... being close pestered 
together in Small romes specially in this tyme of Sommer'. ${ }^{73}$ In the years immediately following Croft's servant's frustrated close alley, moreover, Ambrose Warwick's servant was forestalled from playing a fencing prize at the Bull on Gracious Street (an inn that hosted playing and fencing). The mayor explained only that he prevented him from playing at the Bull specifically — as it 'was somewhat to close for infection' - but permitted him 'to playe in an open place of the Leadenhall more fre from danger and mete for his Comoditie.' ${ }^{74}$ The Bull's 'closeness' has nothing to do with its size, as it frequently hosted fencing prizes, so it must indicate some other feature of the inn. The mayor's suggestion that Warwick's servant may therefore 'lawefully ... playe at the Theater or other open place out of the Citie' may indicate a view of amphitheatrical or outdoor space as structurally and hygienically distinct from a 'close' inner-city space (and preferable in this occasion). We might deduce from this distinction that closeness can also be synonymous with indoor or covered play - for either fencing, play performance, or bowling.

Given this nice distinction, Croft's servant's 'close Allye' suggests a deliberate commercial strategy to double up on the types of space he is able to offer gamesters, gamblers, and spectators. While he already owned a large outdoor space, he sought a smaller and/or potentially covered or indoor bowling area that might cater to a smaller crowd, but that might also be preferable in poorer weather or that might cater to a different clientele (as well as potentially offering different versions of the game). Croft's servant's failed strategy presages the doubling up on playing space that James Burbage attempted in 1596, when he sought to secure the Blackfriars for indoor playing space — smaller, 'closer', and more elite - that would complement their larger 'open place' of the Theatre (or subsequent iterations of this building - an ongoing project for Burbage given the legal wranglings in these years over renewing the lease on the land). The later success of the King's Men in cycling the Blackfriars and the Globe is in some sense Croft's servant's plan for his bowling alley come to fruition.

\section{Naylor in the Blackfriars}

In the years surrounding the arrival of commercial theatrical playing in the Blackfriars - and some twenty years before Burbage's attempt to secure space in the liberty - Naylor's bowling alleys were already generating discourse that theatre historians often characterize as 'antitheatricalism'. Christopher Highley has recently provided nuance to this broad-brush term by showing the complexity of the petition of 1596 against Burbage's playhouse proposal and some residents' potential 
support of a successful playhouse, yet the lens at the Blackfriars has been squarely focused on dramatic playing. ${ }^{75}$ Naylor's activities provide the earliest example of Blackfriars petitions against recreational enterprise, and they generate a model for anti-play rhetoric that opponents later brought to bear on both the First and the Second Blackfriars playhouses. Proprietors' adaptation of former friary structures, moreover, offers an early example of how entrepreneurs could carve commercial 'play' space from post-ecclesiastical land: a model the Shoreditch playhouses, the Blackfriars, and, later, the Whitefriars followed.

More's petitions against the bowling alleys survive in four forms, each providing slightly different details (likely working drafts, with one in presentation hand). The petitions contrast the 'Corrupt gayne' and 'Huere and gaynes' 76 with the Blackfriars' proper character as a 'place of $\lceil$ good order $\urcorner$ Cyvyle and quyet dwelling, as well for preaching and other exercyses of Religion, as also for the suppressing and auoiding of dysorders and anoyaunces. ${ }^{77}$ More, therefore, draws on both the private status of the precinct and its 'godly' reputation, well before it becomes associated with puritan preachers such as Egerton in the later part of the century. The petitions express emphatically practical objections to the bowling alleys, moreover, complaining of the 'swerynge Noyse and Cryinges' and its 'annoyaunce \& disturbance of all the Neighboures', as well as more infrastructural issues: 'Nailor encrocheth apon the quenes highe waie within the sayd prescinct and hath begon the foundacion of a Brick worke there myndinge uerye shortlye to erecte a frame thereupon whereby the quenes Maiesties highe weye there, shalbe greatlye straited'. ${ }^{78}$ In Highley's exploration of the specific neighbourhood conditions and the 'different anxieties, desires, and priorities of local residents', he observes how the petition against Burbage's attempted venture in 1596 contained much more than simply puritan dislike of theatre on a moral, ideological, or doctrinal level; rather, the objections - including the wording of the petition itself — 'eschew religious and biblically inspired objections to playing for pragmatic arguments based on concerns about social order and public health ${ }^{\prime}{ }^{79}$ Precisely these characteristics are present in this earlier petition against Naylor, which prefigure the complaints in 1596 that a 'Comon playhouse ... will ... grow to be a uery great annoyance ... allso a generall inconuenience to all the Inhabitants', that it will gather together 'all manner of uagrant and lewde persons', and that it will (like the swearing and noise of Naylor's alleys) create sound pollution through 'Drummes and Trumpetts'. ${ }^{80}$ The tenor of these objections is also present in More's annoyance at the activities of the First Blackfriars Playhouse in the mid-1580s, when he claims that Farrant misleadingly 'made it a continual house for plays, to the offense of the precinct. ${ }^{81}$ 
Focusing squarely on one small liberty that housed entertainment centres for fencing, playing, bowling, tennis, and dancing within a thirty-year period following its privatization reveals that bowling alleys furnished More with the vocabulary and phraseology to object to various forms of play across the rest of the century. This correlation is in some sense part of a larger cultural and rhetorical move across London in these years in which 'antitheatricalists ... strategically collapsed theatre and games', as Bloom observes. ${ }^{82}$ While some evidence may exist of broader discursive 'tensions between theatres and the venues (such as taverns and parlours) where games like backgammon and cards were played', 83 the example of the early secular years of the Blackfriars provides a rare instance of documented 'play' spaces and one of the earliest place-specific links between theatrical playing and the bowling alley - a 'game' venue, as I show above, more easily matched with playhouse architecture than a parlour (though of equal comparison to the tavern or inn, which we cannot rightly distinguish from 'theatres' given their frequent synonymity in the period). Indeed, Naylor's forgotten alleys, which scholarship has almost entirely overlooked, echo through the liberty's recreational history and are the foundation for later complaints against Farrant's theatre and the petition against Burbage's Second Playhouse.

Naylor also models for these individuals ways of appropriating space for recreational ends. While examples of earlier 'play' exist in the vicinity, ${ }^{84}$ Naylor's bowling alleys seemingly represent a new scale of recreational enterprise - large enough and successful enough to prompt More's response about the huge numbers flocking to spend money there. More contrasts popular 'unlawful' pastimes with Cyvyle and quyet dwelling ... preaching and other exercyses of Religion'. ${ }^{85}$ In turn, he creates an architectural parallelism between Naylor's repurposed land and the formerly sacred space: Naylor is said to have 'procured an interest vnto a voyde place within the seyd precinct, being, at the tyme of the dissolucion of the seyd ffreers, parcell of the Circuyte of theyre owne house and used by theym as a Cloyseter, Comenly Called the Inner Cloyster,' in which 'the seyd Nayler

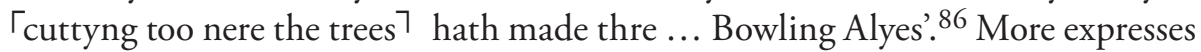
a double architectural and rhetorical opposition, according to which Naylor puts space to improper use - both practically (cutting into the trees, building too near the Queen's highway) — and morally — by going against the appropriate reuse of such space and not fitting appropriately (Protestant) exercises of religion. Despite the overwriting of Catholic space with new forms of worship, More seeks to inscribe in the Blackfriars a Christian propriety that preserves the Blackfriars' sense of sacredness while marrying it with the practical levelheadedness that dominates these and later petitions against play spaces. 
Repurposing ecclesiastical land for commercial ends (what More identifies as 'gain' and 'lucre') is precisely what then happened in Shoreditch with the building of the Theatre and the Curtain (both on former Holywell Priory land, the former clearly on the foundations and surrounded by the buildings of that prior-Priory). The Blackfriars itself is a space self-consciously in dialogue with its past in what Tiffany Stern sees as a ghosting by its earlier functions: 'entering the [Second Blackfriars] theatre ... meant confronting its architectural past'. ${ }^{87}$ Temples, for instance, 'hover off stage as though a functioning religious site is just behind the wall ... sometimes, more daringly, the temple is located where the play itself is taking place' - a way of 'drawing attention to the theatre's religious aura, while making it secular, allowed Shakespeare to exploit the atmosphere of the place without suggesting he felt affiliation with it'. ${ }^{88}$ Inevitably, such metatheatrical techniques do not begin or end with Shakespeare, and the First Blackfriars Playhouse was subject to precisely such play with the history of the 'house': in Anthony Munday's Fedele and Fortunio, a play likely performed at the venue in the late 1570s, Fedele takes up a letter 'and reads it at the lamp, which burneth in the Temple'. ${ }^{89}$ Henry Naylor's enterprise provides an early example of how former 'temple' space might be cleverly and consciously adapted for commercial recreational play: by capitalizing on the existing inner cloisters of the former friary, which are already 'alleys' of a sort, ${ }^{90}$ his bowling trade points to practical building solutions that make a virtue of easily available ex-monastic environments. The rooms of a 'house' or a hall, such as those used in both the First and the Second Blackfriars, clearly presented opportunities for theatrical performance space, and the void ground among former tenements and priory buildings in Shoreditch offered room to create 'open' playing spaces in a rapidly developing suburban locale. Both Naylor and Croft's servant provide concrete examples of the way in which the playing industry develops in tandem with and sometimes in response to the entrepreneurial innovations of bowling alley proprietors and add specific examples to broad instances of antitheatrical commentary and legislation. The shape of antitheatrical discourse, as theatre historians have understood it, owes much to the ways in which bowling alleys were regulated, controlled, and opposed - at local or private levels in a space such as the Blackfriars, and at a city-wide level by the Corporation and the lord mayor.

\section{Conclusion}

Bowling alleys occupy a striking place in the history of London's recreational industries in the second half of the sixteenth century, though scholars have largely 
overlooked them in favour of other entertainment activities. Scholars have often seen playing, in particular, as a discrete entity, but the boom in playhouses from the 1560 s to the 1580 s - and their cultural and socio-economic significance beyond these years - is tied to the wider leisure ecology of London. Central to that ecology is the bowling alley, a contentious space that illustrates mid-tolate Elizabethan practices relating to rented accommodation, building, and overcrowding in a rapidly growing metropolis. In turn, alleys exemplify the possibilities open to 'builders' of recreational enterprises, particularly the conversion of existing spaces or narrow areas between buildings.

Accordingly, I have sought in this article to restore the bowling alley to the history of commercial theatre and to emphasise the centrality of 'conversion' as a crtical paradigm for understanding playhouse construction. Both spaces centre on 'play' as an activity that visitors can enjoy in various ways, and bowling helps advance recent revisionist theatre scholarship by, for instance, Bishop, Bloom, Richard Preiss, and Scott McMillin and Sally-Beth MacLean in decentring the 'closed' narrative-based play to accommodate the wider play performance. ${ }^{91}$ Bowling, therefore, offers potential for reinterpreting the dramaturgy and mixedmode performance (beyond or outside of the playtext) of Elizabethan theatre and for imagining the possible experiential relationships between alley-going and playhouse-going.

The variety of 'play' also helps link bowling alleys with antitheatrical discourse and its developments across the sixteenth century. Antitheatricalists inherited frameworks for their invective from medieval opposition to ludes and various games, and transferred them to commercial dramatic performance in moves that sought to elide the differences between 'game' and play performance. The close study of two examples, here, demonstrates how bowling alleys, with their combined architectural and discursive similarities to playhouses, add historical detail to the contrived vagueness of much surviving antitheatrical writing.

Indeed, the attempts of Naylor and Croft's servant to develop successful and multi-alley sites in the city show how combinations of both indoor and outdoor, large and small, or open and 'close' space can be a useful business model, one that James Burbage, in turn, takes up (equally unsuccessfully, at first) in his pursuit of the Blackfriars. Burbage's attempted venture in the liberty also underlines how bowling supplies the rhetoric for opposition to commercial 'play' that his opponents employ in 1596 as well as earlier in the 1580s against the First Blackfriars Playhouse. Connecting these two institutions in the Blackfriars indicates how commercial theatre developed in cooperation with, and with inspiration from, 
non-theatrical entertainment institutions - at the levels of architectural design, business structure, and legislative action.

These connections will doubtless become of increasing importance as we continue to discover more about the architectural forms and the varied uses of early modern playhouses, as well as their affinities and relationships with other recreational spaces, from victualling houses to neighbouring theatres. Both prior to and beyond the collaborative set-ups in Shoreditch and Southwark, or the imbrication of various entertainment institutions in the Blackfriars, alley spaces - both domestic and recreational - presented would-be playhouse builders with a model for a micro-market: a multipurpose space that offers food, drink, and entertainment to customers within its confines. Such a commercial playing ecology is essential to recover if we are to learn more about the operations of playhouses such as the Curtain and Theatre, whose external spaces and surrounding buildings raise questions about what exactly constituted the boundaries and scope of a 'playhouse' and how wide the range of leisure activities they accommodated may have been. The alley occupied a central place in London's developing entertainment districts, and its scope and significance must push historians to recover a wider appreciation of what 'theatre', and its surrounding industry, encompassed. 


\section{Notes}

1 Gabriel Egan, 'The Theatre in Shoreditch, 1576-1599', in The Oxford Handbook of Early Modern Theatre, ed. Richard Dutton (Oxford, 2010), 172, https://doi.org/10.1093/oxfordhb/9780199697861.013.0011.

2 Mike Huggins, 'Early Modern Sport', in Oxford Handbook of Sports History, ed. Robert Edelman and Wayne Wilson (Oxford, 2017), 116, https://doi.org/10.1093/ oxfordhb/9780199858910.013.16.

3 Gervase Markham, Countrey Contentments (London, 1615; stc: 17342), P2v.

4 John Stow, Suruey of London (London, 1598; sтc: 23341), Aalv.

5 London Metropolitan Archives MS COL/RMD/PA/01/001, 131; see the section on 'Croft's Servant' below.

6 John Earle, Microcosmographie (London, 1628; stc: 7441), H2v.

7 Ibid.

8 Oxford English Dictionary (OED) Online, s.v. 'gamester', 1.a and 2.a.

9 Surrey Historical Centre MS LM 413/1-414, ca1580s.

10 Ibid.

11 Glynne Wickham, Early English Stages, 2 vols (1963; rpt London, 2002), 2.32.

12 Lawrence Clopper, Drama, Play, and Game: English Festive Culture in the Medieval and Early Modern Period (Chicago, 2001).

13 British Library Sloane MS 2530.

14 Erika Lin, 'Festivity', Early Modern Theatricality, ed. Henry S. Turner (Oxford, 2013), 212-29, https://doi.org/10.1093/oxfordhb/9780199641352.013.11.

15 Ibid., 213-14.

16 Tom Bishop, 'Shakespeare's Theater Games', Journal of Medieval and Early Modern Studies 40.1 (2010), 66.

17 'Middlesex Sessions Rolls: 1612', in Middlesex County Records: Volume 2, 160325, ed. John Cordy Jeaffreson (London, 1887), 78-84. British History Online, http://www.british-history.ac.uk/middx-county-records/vol2/.

18 Edmund Gayton, Notes upon Don Quixot (London, 1654; Wing: 145:06 ), Mm3r.

19 Paul Hentzner, Paul Hetnzner's Travels in England, trans. Horace Walpole (London, 1797).

20 For a summary, see Julian Bowsher, 'Twenty Years On: The Archaeology of Shakespeare's London Playhouses', Shakespeare 7.4 (2011), 452-66.

21 Glynne Wickham, ed. English Professional Theatre (Cambridge, 2001), 268.

22 Henry Chettle, Kind-Harts Dream (London, 1590; sтc: 5123), C3r. 
23 Gina L. Bloom, Gaming the Stage: Playable Media and the Rise of English Commercial Drama (Chicago, 2018), 3, https://doi.org/10.3998/mpub.9831118.

24 SHC MS LM 413/1.

25 See, for contemporary examples, LMA MS COL/CA/01/01/022 (years 1581-83).

26 T.F., Newes from the North (London, 1579; sтC: 20462), F4r.

27 Bloom, Gaming the Stage, 1.

28 Andy Kesson, 'Playhouses, Plays, and Theater History: Rethinking the 1580s', Forum, ed. Andy Kesson, Shakespeare Studies 45 (2017), 27.

29 oED Online, s.v. 'Alley', 7.

30 LMA MS COL/CC/01/01/020-21. f 127v.

31 LMA MS COL/CC/01/01/019, f 153r; see also LMA MS COL/CC/01/01/019, f $243 r$.

32 LMA MS COL/CA/01/01/022, f 136v.

33 See Ian Archer, 'The City of London and the Theatre', in The Oxford Handbook of Early Modern Theatre, ed. Richard Dutton (Oxford, 2010), 407-8, https://doi.org/10.1093/oxfordhb/9780199697861.013.0024.

34 LMA MS COL/CC/01/01/020-21, f 505r.

35 Chettle, Kind-Harts Dream, F1v-2r. Intriguingly, a number of the landowners listed in the records of the Court of Common Council and the aldermen are women (see, for instance, repeated infractions by Margaret Hawkins, REPS 17, 427v, 20 January 1573). In his misogynistic sketch of such an owner, Chettle chooses the landlady rather than the landlord to exemplify these practices. These instances raise the possibility that many of London's anonymous bowling alleys may too have been owned and run by women, just as Margaret Brayne, Ellen Burbage, and Anne Farrant are involved in various ways with playhouses in these years.

36 Tara Hamling and Catherine Richardson, A Day at Home in Early Modern England (Yale, 2017), esp. 12-22.

37 William C. Baer, 'The House-Building Sector of London's Economy, 1550-1650', Urban History 39.3 (2012), 409-30.

38 Ibid.

39 The National Archives, Kew MS REQ 2/184/45.

40 NAK MS STAC 5/G17/29.

41 Guildhall Library, London MS 4329/1, f 128v; NAK MS KB 27/1229, m.30.

42 GLL MS 11,571/6, 434v.

43 NAK MS KB 27/1229/m.30.

44 GLL MS 4329/1, f 128v.

45 GLL MS C295, 483. 
46 Herbert Berry, 'The First Public Playhouses, Especially the Red Lion', Shakespeare Quarterly 40.2 (1989), 148.

47 In 1576, one Robert Burbidg appears in the carpenters account book, binding an apprentice, Henry Burbidge (possibly his son) — the year of the building of the Theatre. He also took receipts for timber that year of 4 shillings and 8 pence. William Ingram surmises that Robert is James Burbage's brother, and the coincidence of relationship between joiner Burbage and carpenter Robert in these years provides fascinating food for thought on possible influences of the carpenters' company on recreational space beyond the examples set out above.

48 S.P. Cerasano, 'The Transitory Playhouse: Theatre, Rose, and Globe', in The Text, the Play, and the Globe: Essays on Literary Influence in Shakespeare's World and his Work in Honor of Charles R. Forker, ed. Joseph Candido (Madison, 2016), 95-120.

49 LMA MS COL/CA/01/01/019, f 153r.

50 Folger Shakespeare Library MS L.b.446, 27 August 1576.

51 Qtd in Irwin Smith, Shakespeare's Blackfriars Playhouse: Its History and Its Design (New York, 1964), 467.

52 On dating and discussion of possible identification of these buildings, see Herbert Berry, 'The View of London from the North and the Playhouses in Holywell', Shakespeare Survey (2000), 196-212.

53 Richard West, The Court of Conscience (London, 1607; sTC: 25263), D3v.

54 Heather Knight, 'The Curtain Rises', talk given at Hackney House, 21 July 2018. See also, Knight, e-mail messages to the author, September 2018.

55 David J. Amelang, 'Comparing the Commercial Theaters of Early Modern London and Madrid', Renaissance Quarterly 71 (2018), 64.

56 Egan, 'The Theatre in Shoreditch', 172.

57 On this subject, see Laurie Johnson, Shakespeare's Lost Playhouse: Eleven Days at Newington Butts (London, 2017).

58 NAK MS REQ 2/87/74.

59 NAK MS REQ 2/184/45.

60 For background on the Theatre's surrounding buildings, see MOLA's post-excavation report: '4-6 New Inn Broadway, London, EC2A; Post-excavation assessment' (London, 2013).

61 See various testimonies in NAK MS REQ 2/184/45.

62 Joachim Frenk, 'Games', in The Ashgate Research Companion to Popular Culture in Early Modern England, ed. Andrew Hadfield, Matthew Dimmock, and Abigail Shinn (Abindgon, 2014), 223.

63 Clopper, Drama, Play, and Game, 69. 
64 Glynne Wickham, 'The Popular Image of the Stage Player', English Professional Theatre, 1530-1660, ed. Glynne Wickham, Herbert Berry, and William Ingram (Cambridge, 2000), 167.

65 LMA MS COL/RMD/PA/01/001, 131.

66 LMA MS COL/RMD/PA/01/001, 132

67 Stow, Suruey of London, Aalv.

68 LMA MS COL/RMD/PA/01/001, 132.

69 On taverns, see William Fleetwood shutting down over 200 alehouses in 1575 in British Library Lansdowne MS 20, f 20r.

70 See privy council order on 28 July 1597 about pulling down the Theatre and the Curtain, NAK MS PC 2/22, 327, and control of the permitted amount of playhouses surrounding the building of the Fortune, 22 June 1600, NAK MS PC 2/25, 223, 230.

71 LMA MS COL/RMD/PA/01/001, 99

72 LMA MS COL/CC/01/01/022, 68r.

73 LMA MS COL/CC/01/01/019, f 168r.

74 LMA MS COL/RMD/PA/01/001, 384.

75 Christopher Highley, 'Theatre, Church, and Neighbourhood in the Early Modern Blackfriars', in The Oxford Handbook of the Age of Shakespeare, ed. Malcolm Smuts (Oxford, 2016), 616-32, https://doi.org/10.1093/oxfordhb/9780199660841.013.35.

76 Surrey Historical Centre, Woking MS LM 414; LM 413/3.

77 SHC LM 414.

78 SHC LM 413/1.

79 Highley, 'Theatre, Church, and Neighbourhood', 619, 621.

80 NAK MS SP 12/260, 176.

81 Qtd in Smith, Shakespeare's Blackfriars Playhouse, 467.

82 Gina Bloom, 'Games', in Early Modern Theatricality, ed. Henry S. Turner (Oxford, 2013), 196.

83 Ibid.

84 These include 'ij tennys playes', Folger Shakespeare Library MS L.b.393, ca 1550s and L.b.414, ca 1560s.

85 SHC LM 414.

86 Ibid.

87 Tiffany Stern, “'A Ruinous Monastery”: The Second Blackfriars Playhouse as a Place of Nostalgia', in Moving Shakespeare Indoors: Performance and Repertoire in the Jacobean Playhouse, ed. Andrew Gurr and Farah Karim-Cooper (Cambridge, 2014), 102, https://doi.org/10.1017/CBO9781139629195.008.

88 Ibid., 104. 
89 Anthony Munday, Fedele and Fortunio (London, 1585; stC: 19447), C3r-v.

90 oED Online, s.v. 'Alley', 6c.

91 Richard Preiss, Clowning and Authorship in Early Modern Theatre (Cambridge, 2014), https://doi.org/10.1017/CBO9781139567794; Scott McMillin and Sally-Beth MacLean, The Queen's Men and Their Plays (Cambridge, 1998). 
